\title{
Size-dependent variation in the functional role of the parrotfish Scarus rivulatus on the Great Barrier Reef, Australia
}

\author{
Roberta M. Bonaldo*, David R. Bellwood \\ Australian Research Council Centre of Excellence for Coral Reef Studies, and School of Marine and Tropical Biology, \\ James Cook University, Townsville, Queensland 4811, Australia
}

\begin{abstract}
Biodiversity loss and fishing-induced changes in the size distributions of fishes can impact ecosystem function on coral reefs. These changes have led to an urgent need for studies on the particular roles of species to underpin effective coral reef management. The present study focuses on the feeding ecology of 6 size classes (from 2.5 to $30 \mathrm{~cm}$ total length) of Scarus rivulatus (family Labridae), one of the most abundant parrotfishes on the Great Barrier Reef, Australia. Individuals in all 6 size classes strongly selected the epilithic algal matrix for foraging and rejected other substratum types, including coral, macroalgae and sand. The 6 size classes also had similar feeding rates (bites $\mathrm{min}^{-1}$ ) and diel feeding patterns, with higher feeding activity during the afternoon. However, the size of grazing scars by $S$. rivualtus differed significantly among the 6 size classes, with small individuals scraping a greater substratum area per unit biomass and larger individuals taking a greater volume of material per unit biomass. Thus, biomass cannot be not be viewed as a proxy for ecosystem impact; different sized individuals of $S$. rivulatus, and probably other parrotfish species, have a markedly different impact on the reef substratum. Selective harvesting of large individuals will therefore change the functional role of this species. These results emphasize the importance of considering the size of individuals when evaluating the role of reef species in ecosystem process. These intraspecific functional differences will be critical when formulating reef management strategies and evaluating the impact of fishing activity on reef ecosystems.
\end{abstract}

KEY WORDS: Herbivory · Coral reef fish · Resilience · Fishing impacts · Parrotfish · Functional redundancy

Resale or republication not permitted without written consent of the publisher

\section{INTRODUCTION}

The loss of biodiversity and the modification of sizefrequency distributions through fishing activity can have direct consequences for marine ecosystem function (e.g. Hughes et al. 2005). On coral reefs, these changes have highlighted the urgent need for studies on the particular role of reef species in ecosystem processes that can underpin effective coral reef management (McClanahan et al. 1997, Bellwood et al. 2003, Hughes et al. 2003, Mumby et al. 2006, Wilson et al. 2006). In this context, studies on the functional role of species have become an important prerequisite for coral reef management, since they can provide important information about the extent of functional redundancy and potential coral reef resilience.

Although there has been considerable interest in the functional role of species, relatively few studies on this subject have been conducted on Indo-Pacific coral reefs, one of the world's most diverse and threatened ecosystems. For example, although herbivory is recognized as one of the key factors shaping the benthic community structure of coral reefs (Lewis \& Wainwright 1985, McClanahan et al. 1997, McCook 1999, Burkepile \& Hay 2006, Littler \& Littler 2006, Mumby et al. 2006), literature on the quantitative ecosystem 
impacts of individual herbivorous taxa on these systems is limited (McManus \& Polsenberg 2004). This small dataset of measured ecosystem impacts for individual taxa partly reflects the tendency for herbivory to be viewed as a uniform process (cf. Choat 1991). However, several studies have shown that grazing by distinct groups of herbivorous fishes can have different effects on the algal community succession (e.g. Hixon \& Brostoff 1996, Ceccarelli et al. 2005), with individual species having markedly different functional roles (e.g. Bellwood et al. 2006, Hoey \& Bellwood 2007).

Very little is known of intraspecific variations on the functional role of reef fishes on Indo-Pacific reefs since most studies describe functional roles as a speciesspecific trait. However, a key question remains: Does size affect the functional role of fishes on coral reefs? Many coral reefs around the world suffer from a depletion of fish stocks, especially of large individuals, the main target of commercial and artisanal reef fisheries (McClanahan et al. 1997, Nyström et al. 2000, Bellwood et al. 2003, Floeter et al. 2006, Mumby et al. 2006). As a consequence, on reefs with intense fishing there is an effective reduction in the overall size structure of fishes. This has unknown functional implications. During its development, a fish can greatly change its size, shape, colour and behaviour; thus, individuals of a same species may play markedly different functional roles in the ecosystem throughout their lives. Ontogeny is well known to be important in ecology, but it has not been evaluated from an ecosystem perspective on coral reefs (cf. Hoey \& Bellwood 2007). This paper redresses this problem for the IndoPacific parrotfish species Scarus rivulatus.

The parrotfishes (Labridae; formely Scaridae) are among the predominant reef herbivores in terms of population density, biomass and algal consumption, and are well known for their importance in the dynamics and diversity of coral reefs (McClanahan et al. 1997, Hughes et al. 2003, Bellwood et al. 2004, Mumby et al. 2006). Size-related changes in the functional role of individual parrotfish species have been studied in the Caribbean (e.g. Bruggemann et al. 1994a,b), but relatively few species have been examined on Indo-Pacific coral reefs (but see Bellwood 1988, Fox \& Bellwood 2007).

Scarus rivulatus was selected because it is the most abundant scarid on the inner-shelf Great Barrier Reef, Australia (GBR), and may therefore exert a significant functional role in reef ecosystem processes (Fox \& Bellwood 2007, Hoey \& Bellwood 2007, Mantyka \& Bellwood $2007 a, b)$. In order to understand the impact of size on functional roles, this study characterized the feeding activity of 6 different size classes (from 2.5 to $30 \mathrm{~cm}$ total length) of $S$. rivulatus on an inner reef of the GBR. The specific aims were (1) to provide a broad overview of the ontogeny of the feeding behaviour of S. rivulatus, (2) to quantify the feeding activity of 6 size classes of $S$. rivulatus, and (3) to evaluate the potential extent of ontogenetic variation in the impact of $S$. rivulatus on the reef substratum.

\section{MATERIALS AND METHODS}

Study site and general methodology. This study was conducted between February and July 2007 at Orpheus Island $\left(18^{\circ} 35^{\prime} \mathrm{S}, 146^{\circ} 20^{\prime} \mathrm{E}\right)$, a granitic island in the inner shelf region of the GBR, approximately $20 \mathrm{~km}$ off the coast of North Queensland. Two sites within Pioneer Bay, located on the leeward side of the island, were used in the study. To standardize observations, all were conducted in the same reef zone (outer flat).

Feeding rates, substratum selection and the size of grazing scars (area and volume of material removed during feeding) were quantified for 6 size classes of Scarus rivulatus: 2.5 to $5 \mathrm{~cm}, 6$ to $10 \mathrm{~cm}, 11$ to $15 \mathrm{~cm}$, 16 to $20 \mathrm{~cm}, 21$ to $25 \mathrm{~cm}$ and 25 to $30 \mathrm{~cm}$ total length (TL). Observations on substratum selection and feeding rates were all conducted during the austral summer (February to March) to minimise temperature or seasonal effects. All observations were taken within $3 \mathrm{~h}$ of high tide to minimise the impact of tides.

Feeding rates. Observations on the feeding rates (bites $\mathrm{min}^{-1}$ ) of individual size classes of Scarus rivulatus were carried out over 10 consecutive days by SCUBA divers. The observations were made over 4 periods during the day: morning (08:00 to 11:00 h), middle of the day (11:01 to $14: 00 \mathrm{~h}$ ), afternoon (14:01 to $16: 00 \mathrm{~h}$ ) and late afternoon (16:01 to 18:00 h). The sample unit was a 1 min period; divers recorded the fish's size class, the start time of the observation and the total number of bites taken. At least 30 ind. of each size class were followed during each period at each study site. No similarly-sized individual was followed over successive periods to minimize the risk of collecting non-independent data. Observations were discontinued if the fish showed a visible response to the diver.

Substratum selection. The substratum selection by different size classes of Scarus rivulatus was assessed by comparing the number of bites taken on each substratum type and the availability of that substratum at each site. Individuals were located during haphazard surveys at each site. Once a focal individual was located, it was classified into one of the 6 size categories and followed at a distance of at least $2 \mathrm{~m}$ until the fish was observed to bite the substratum. The substratum type was then classified into 5 categories: epilithic algal matrix (EAM, sensu Wilson et al. 2003), hard coral, macroalgae (Sargassum spp. and Turbinaria spp.), sand and soft coral. A total of 60 ind. of each size class 
was observed for the substratum selection and only 1 feeding observation was recorded for each individual to maximize the independence of replicate observations.

Relative proportions of the components of benthic cover at each study site were obtained using a lineintercept method (Choat \& Bellwood 1985). A $10 \mathrm{~m}$ transect tape was laid haphazardly across the reef substratum. At each $1 \mathrm{~m}$ interval along the tape, the diver recorded the nature of the substratum directly underneath the tape and at points $1 \mathrm{~m}$ perpendicular to the left and right of the tape. The substratum type was classified into the same categories used for the feeding bites of Scarus rivulatus. A total of 12 replicate $10 \mathrm{~m}$ transects were conducted at each of the 2 study sites ( $\mathrm{n}=24)$.

Grazing impact. The grazing impact of different size classes of Scarus rivulatus was assessed by measuring the grazing scars of individuals in each class. The term 'impact' herein refers to the immediate consequences of feeding activity, i.e. the removal of algal material, and does not necessarily reflect long-term changes to the community composition of the EAM. The nature (i.e. if fish bite exposed the substratum or not) and size (maximum area and volume) of grazing scars of $S$. rivulatus were measured by SCUBA divers, who followed focal individuals until the exact location of a bite could be seen. TL of the individual was estimated, exposure of substratum was recorded and maximum length $\left(L_{\max }\right)$, width $\left(W_{\max }\right)$ and depth $\left(D_{\max }\right)$ of the grazing scar was measured with callipers. The size of grazing scars was calculated in terms of maximum area $\left(L_{\max } \times\right.$ $W_{\text {max }}$, assuming a rectangle) and maximum volume $\left(L_{\max } \times W_{\max } \times D_{\max }\right)$. The maximum depth of the scar was measured by the difference of the algal height inside and on the margin of the grazing scar. In order to provide an adequate comparison between the different size classes of $S$. rivulatus, all the grazing scar measurements were conducted on the same substratum type (dead coral matrix covered by EAM). At least 30 grazing scars of each $S$. rivulatus size class were measured and analysed per study site. Because of their reduced size, scars of some individuals in the smallest size class were observed in aquarium tanks and measured under a stereomicroscope.

Quantification of the feeding impact per unit body mass of the 6 size classes was based on the estimated total number of bites between 08:00 to 18:00 h multiplied by the size of an individual bite (area and volume) and divided by the body mass of each size class. Body length estimates were converted to biomass estimates using published length-weight relationships (Kulbicki et al. 2005).

Analyses. Feeding rates of Scarus rivulatus were compared using a 3-way ANOVA, with study sites, size class and time of day as fixed factors. The number of bites of $S$. rivulatus per substratum type at the 2 sites was compared using a chi-square contingency table. Selection of foraging substrata by the 6 size classes was measured based on Strauss's linear resource selection index ( $L$ in Strauss 1979) and $95 \%$ confidence intervals (CI) were calculated.

The number of grazing scars exposing the substratum between the 2 study sites was compared using a chi-square contingency table. The number of grazing scars exposing the substratum among the 6 size classes was compared using a chi-square for goodness of fit. To check if there was a geometric relationship between fish and scar size, linear regressions were made of scar area to fish $\mathrm{TL}^{2}$ and scar volume to fish $\mathrm{TL}^{3}$, with TL as the independent factor and scar size the dependent variable. We also calculated the slope of a log-log graph of scar area and fish $\mathrm{TL}^{2}$, and scar volume to fish $\mathrm{TL}^{3}$ to examine the allometric coefficient of fish TL and bite size.

Size (area and volume) of grazing scars of different size classes was compared using a 2-way ANOVA, with study site and size class as the fixed factor on each test. In such analyses, study site and fish size class were the fixed factors and the substratum removal was the variable. The overall quantification of the feeding impact per unit body mass of the 6 size classes was compared using the compound errors around the mean for each size class. Compound errors for the impact variables (feeding rates, grazing scar size) for each size class were calculated using the 2-term version of Goodman's estimator, with mean substratum removal \pm SE per kg of fish and total number of bites $d^{-1} \pm$ SE as terms (modified from Bellwood 1995). Total bites $\mathrm{d}^{-1}$ is based on a $10 \mathrm{~h}$ day and the mean $\pm \mathrm{SE}$ feeding rate is calculated as the sum of the mean \pm SE feeding rates for each hour between 08:00 to 18:00 $\mathrm{h}$ for each size class.

Before all parametric tests, data were examined for normality and homogeneity of variance using the D'Agostino-Pearson test and residual analysis. No transformations were needed, since the data met the required assumptions. Where differences were found to be significant in an ANOVA, post-hoc tests (Tukey's HSD) were used to examine patterns.

\section{RESULTS}

There were no differences detected in the feeding rates of Scarus rivulatus between sites or among fish size groups, but there was a highly significant time of day effect (Table 1), with all size classes foraging less during early morning and exhibiting a feeding activity peak during the middle of the afternoon (Fig. 1). Most 
Table 1. Scarus rivulatus. Three-way ANOVA examining feeding frequencies (bites $\mathrm{min}^{-1}$ ) at Pioneer Bay, Orpheus Island, Great Barrier Reef. bold: $\mathrm{p}<0.05$

\begin{tabular}{|lrrrrc|}
\hline Source & SS & df & MS & $F$ & p \\
\hline Site & 186.5 & 1 & 186.5 & 1.15 & 0.28 \\
Size & 1813.6 & 5 & 362.7 & 2.24 & 0.05 \\
Time & 4955.2 & 3 & 1651.7 & 10.22 & $<\mathbf{0 . 0 0 1}$ \\
Site $\times$ Size & 3670.2 & 15 & 244.6 & 1.51 & 0.20 \\
Site $\times$ Time & 606.4 & 5 & 202.1 & 1.25 & 0.29 \\
Time $\times$ Size & 3624.5 & 15 & 241.6 & 1.49 & 0.10 \\
Site $\times$ Size $\times$ Time & 1453.6 & 15 & 96.9 & 0.60 & 0.88 \\
\hline
\end{tabular}

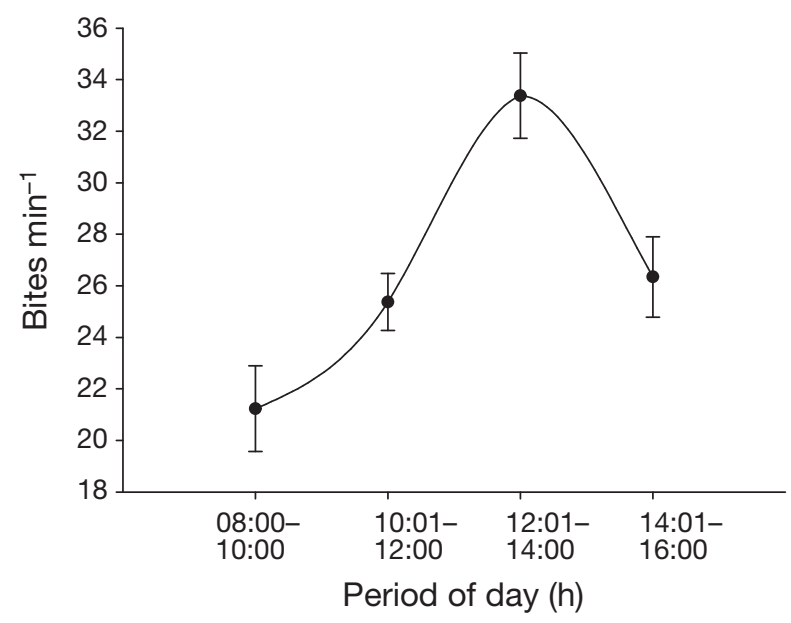

Fig. 1. Scarus rivulatus. Feeding frequencies (bites $\mathrm{min}^{-1}$, mean \pm SE) at Pioneer Bay, Orpheus Island, Great Barrier Reef

of the individuals in the largest size class of $S$. rivulatus were terminal phase (TP) individuals, while the 4 smallest size classes were juveniles or initial phase (IP) adults. In terms of substratum selection, no differences were found in the distribution of the total number of bites per substratum type between the 2 study sites $\left(\chi^{2}{ }_{5}=1.25, p>0.9\right)$. The 6 size classes also showed the same substratum selection pattern: a strong preference for EAM and rejection of other substratum types. The Strauss's linear resource selection index for substratum types overlapped for all size classes and the $S$. rivulatus selection index was therefore based on pooled size-class data (Fig. 2).

No differences were found between sites in the distribution of bite scars exposing the substratum among the 6 size classes $\left(\chi^{2}{ }_{5}=1.0, \mathrm{p}>0.9\right)$. However, the relative occurrence of grazing scars that exposed the substratum did differ among the 6 classes $\left(\chi^{2}{ }_{5}=121.18, \mathrm{p}<\right.$ 0.01 ), with an increase in substratum exposure with increasing fish TL (Fig. 3a). Small individuals (2.5 to $10 \mathrm{~cm}$ TL) usually only cropped the algal surface and their grazing scars were usually marked only by a

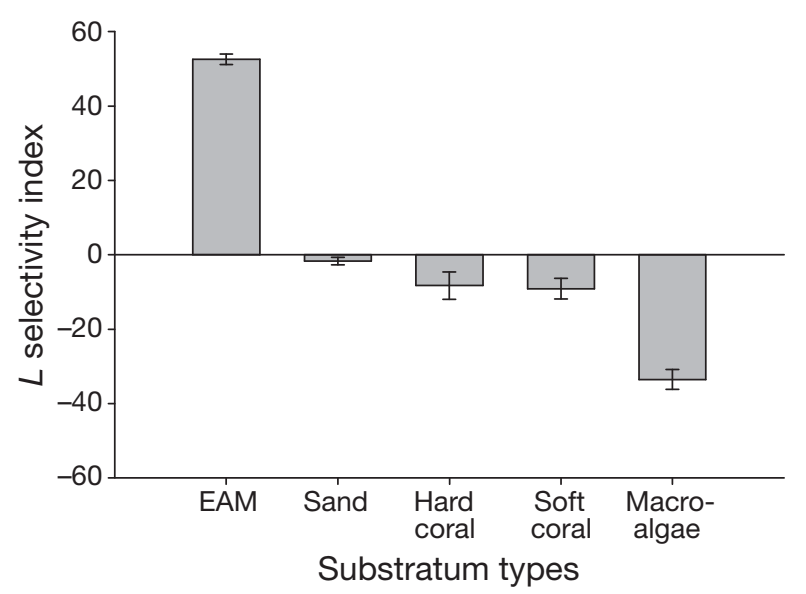

Fig. 2. Scarus rivulatus. Substratum selection (Strauss's linear index $[L]$, mean $\pm 95 \% \mathrm{CI}$ ) at Pioneer Bay, Orpheus Island, Great Barrier Reef. Values of the $95 \%$ CI above/below zero indicate preference/avoidance. EAM: epilithic algal matrix
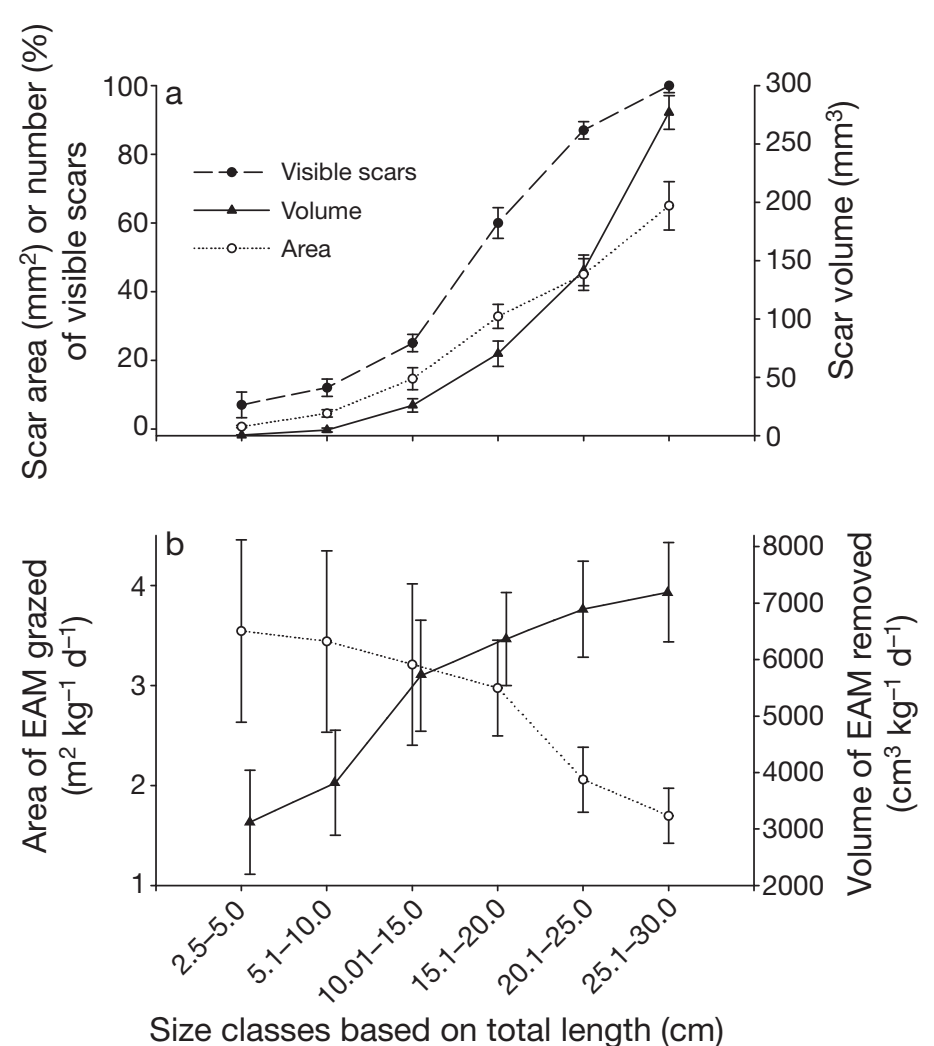

Fig. 3. Scarus rivulatus. Epilithic algal matrix (EAM) removal by 6 size classes (a) per individual and (b) per unit body mass at Pioneer Bay, Orpheus Island, Great Barrier Reef. Values are means \pm SE. In (a) error terms are based on at least 60 ind. per size class; for (b) SE is a combined error term based on scar size and a $10 \mathrm{~h}$ feeding day (details in 'Results')

shallow depression in the EAM. In contrast, large individuals always removed all the algal cover from the substratum and exposed the calcareous surface. 
Bite scar area was linearly related to $\mathrm{TL}^{2}\left(\mathrm{r}^{2}=0.97\right.$, $\left.F_{1}=4114, \mathrm{p}<0.001\right)$ and volume was linearly related to $\mathrm{TL}^{3}\left(\mathrm{r}^{2}=0.97, F_{1}=7024, \mathrm{p}<0.001\right)$. The slope of the log-log relationships of $\mathrm{TL}^{2}$ to bite area and $\mathrm{TL}^{3}$ to bite volume were $0.98 \pm 0.01$ and $0.93 \pm 0.02$, respectively. Both were approximately isometric (with negligible negative allometry).

The area and volume of grazing scars were similar between the 2 study sites ( $p>0.70$ for both analyses), but differed among the 6 size classes, with larger fishes removing more area $\left(F_{5,186}=1431, \mathrm{p}<0.001\right)$ and volume $\left(F_{5,186}=1585, \mathrm{p}<0.001\right)$ than smaller individuals (Fig. 3a). The greatest differences in the size of grazing scars were observed in terms of volume (Fig. 3a).

Standardized EAM removal per $\mathrm{kg}$ of fish differed markedly among the 6 size classes. Large individuals removed the smallest substratum area per unit body mass but the largest EAM volume per body mass (Fig. 3b). Fundamentally, $1 \mathrm{~kg}$ of biomass of small individuals exhibited a different ecosystem impact to $1 \mathrm{~kg}$ of large individuals.

\section{DISCUSSION}

Scarus rivulatus exhibited limited among-size variation in most ecological variables, but when considered in terms of functional roles - especially per unit biomass - small and large individuals displayed a markedly different ecosystem impact. In terms of feeding frequencies, the patterns were very uniform; all $S$. rivulatus size classes fed more frequently during the middle of the day. This result is very similar to the daily feeding pattern of other nominally herbivorous reef fish species (Bruggemann et al. 1994b, Bellwood 1995, Zemke-White et al. 2002). The higher feeding frequency of herbivorous fishes during the afternoon has been explained by the better nutritional quality of algae at this time (Bruggemann et al. 1994b, Bellwood 1995, Zemke-White et al. 2002). This diel feeding pattern seems to be particularly relevant to species that feed on epilithic algae and detrital aggregations (Zemke-White et al. 2002), which is probably the case for $S$. rivulatus in the present study.

The present study found no significant differences in the feeding rates of the 6 size classes of Scarus rivulatus, which is in accordance with a previous study of this species at the same study site (see Fox \& Bellwood 2007). However, these results contrast with a number of studies on the feeding activity of other parrotfish species, which have found that large individuals, especially TP males, usually have lower feeding rates than juveniles and IP adults (e.g. Bruggemann et al. 1994a, Van Rooij et al. 1996b, Bonaldo et al. 2006). In these studies, the differences were explained by the territori- ality of TP males, which usually spend a lot of time patrolling feeding and breeding territories and evicting conspecifics. We propose 2 explanations for the similarities in the feeding rates of different size classes of $S$. rivlautus: (1) TP males of this species are not territorial and, thus, forage as frequently as juveniles and IPs; or (2) the area where both studies on $S$. rivulatus were conducted (Pioneer Bay, Orpheus Island) is a feeding area where TP males do not display territorial behaviour. The latter hypothesis is supported by previous studies on parrotfish species in the Caribbean, which found that the behaviour of TP males is highly variable depending on the location of individuals (e.g. Van Rooij et al. 1996a). However, further investigations on the social system of parrotfishes in the GBR are needed.

Substratum selection was also similar with the 6 Scarus rivulatus size classes; all selected the EAM and strongly rejected macroalgae. The EAM is widely recognized as a substratum rich in sediment and detritus and is of high nutritional value (Crossman et al. 2001, Purcell \& Bellwood 2001, Wilson et al. 2003). In contrast, macroalgae are widely recognized as having many characteristics (e.g. secondary compounds, low nutritional value) which may deter feeding by fishes (Hay 1991). Our results highlight the importance of EAM as the main feeding source of many herbivorous reef fish species and support previous studies, which found that many 'herbivorous' reef fishes (nominally herbivorous fishes sensu Choat et al. 2002) feed mostly on detritus and the EAM rather than macroalgae (e.g. Choat et al. 2002, Wilson et al. 2003, Crossman et al. 2005). Moreover, our results provide direct in situ support of experimental observations that $S$. rivulatus avoids macroalgae (Mantyka \& Bellwood 2007a,b).

The similarities in the diel feeding patterns and selection of feeding substrata among the 6 size classes of Scarus rivulatus are also in accordance with the findings of previous studies on the feeding ecology and behaviour of other parrotfish species (e.g. Bruggemann et al. 1994c, Bonaldo et al. 2006). These results suggest that many aspects of parrotfish feeding do not change throughout the parrotfish life cycle. However, while some patterns apparently do not change as these fishes grow, others do-especially those related to the impact of their jaws. For example, a number of studies on the feeding ecology of parrotfishes on both Atlantic and Pacific reefs have found significant differences in the impact of different size classes on the reef substratum (Bruggemann et al. 1994b, Fox \& Bellwood 2007). These differences suggest that distinct size classes of parrotfishes may play different roles in shaping the benthic community structure.

In the present study, large Scarus rivulatus individuals left grazing scars markedly larger in volume than grazing scars produced by small individuals and usu- 
ally removed not only the algae and associated particulate material, but also dislodged small fragments of the underlying consolidated reef matrix and exposed the calcareous surface. Small S. rivulatus, however, usually only cropped the algal surface and had little or no visible effect on the EAM or consolidated substratum. A similar pattern has been seen in 2 Caribbean species, in which large individuals produced bites with visible grazing scars up to 4 times more frequently than small individuals (Bruggemann et al. 1994b). Large parrotfish individuals seem to affect both algal cover and the underlying substratum, and are responsible for the effective removal of algae and for opening new colonization sites on the reefs. Such variation shows that different sized parrotfishes may differ not only on their quantitative impact on the substratum (the grazed area), but also on how they influence the benthic structure of reefs (the extent and severity of algal removal).

This difference among size classes is most clearly exemplified by the standardized data: area and volume removed per $\mathrm{kg}$ of fish. The EAM volume per $\mathrm{kg}$ of large individuals is much larger than the volume per $\mathrm{kg}$ of small individuals, whereas small individuals graze a much larger area of substratum per unit body mass. Thus, the importance of these small individuals probably lies in their activity of cropping the algal surface, which may be responsible for controlling algal height. Thus, different sized individuals of parrotfishes may have markedly different roles in shaping the benthic community structure.

The functional differences in the grazing effects of small and large individuals of Scarus rivulatus reflects a simple scaling relationship between size of grazing scars and fish body size $\left(\mathrm{TL}^{2} \times\right.$ scar area, $\mathrm{TL}^{3} \times$ scar volume). These relationships suggest a strong linear relationship between fish size and the amount of substratum removed and, thus, that the grazing impact of S. rivulatus is highly dependent on its body size. In both cases, the relationship was approximately isometric, suggesting that the changes are directly linked to a change in size rather than developmental state. These same functions were found in an excavating and a scraping species (sensu Bellwood \& Choat 1990) in the Caribbean (Bruggemann et al. 1994b). These findings suggest that this may be a general relationship that applies to most scarid species. Thus, grazing by largebodied scarids in general will probably have a distinctly different impact on the substratum than small conspecifics. Although this relationship must be tested in more species before it can become a valid generalization, it appears that large-bodied scarids may have a particularly strong effect on the benthic structure and that management rules must consider not only species composition, but fish size as well.
A previous study at Orpheus Island showed a gradient in herbivory across reef zones, with both grazing pressure and abundance of large-bodied herbivorous fishes higher at the reef crest (Fox \& Bellwood 2007). The same study also found a negative correlation between the estimated impact of herbivorous fishes and macroalgal abundance across the gradient, with the crest presenting the highest herbivorous biomass and the lowest macroalgal cover (Fox \& Bellwood 2007). The current study complements these findings, in that it indicates that the gradient in fish herbivory would be even greater had fish size been considered. The inner flat is dominated by small individuals, so that the removal of algal volume is minimal. On the other hand, the crest is highly grazed by large-bodied individuals; thus, the removal of algal volume would be much higher than on the flat. The present study lends further support to the herbivore-induced disturbance model of algal community composition (Steneck \& Dethier 1994), which predicts that low grazing intensities would lead to the development of climax communities characterized by slow growing taxa, such as macroalgal species.

The present findings probably apply to most scraping Scarus species (sensu Bellwood \& Choat 1990), as they possess a relatively uniform morphology and feeding ecology (Bellwood \& Choat 1990). Moreover, given the morphological differences within excavating species (e.g. Bolbometopon spp., Chlorurus spp.), it is probable that this group will exhibit an even greater change in impact with size. Preliminary observations at the study site suggest that the grazing effects of small individuals of scraping and excavating species are similar, but that large-bodied excavators have stronger effects on the substratum than large-bodied scrapers. A comparable pattern was found in the Caribbean for the scraper Scarus vetula and the excavator Sparisoma viride (Bruggemann et al. 1994b). Thus, for both scrapers and excavators, size may be a critical determinant of ecosystem function.

The relationships presented above suggest that large-bodied parrotfishes may have a more significant role in the effective removal of the EAM than small individuals. Although the impact measured in the current study refers to the direct removal of the EAM, experimental studies suggest that this type of activity will have long-term impacts on the community composition of the benthic substratum (McCook 1999). During reef degradation and phase shifts, coral decline may be facilitated or accompanied by a proliferation of algal turfs (Diaz-Pullido \& McCook 2004, McManus \& Polsenberg 2004, Birrell et al. 2005, Hughes et al. 2007). This suggests that large individuals of Scarus rivulatus may have a more significant role than small individuals in the maintenance of the benthic structure 
community of coral reefs and for the prevention of phase shifts in these ecosystems.

As a consequence, it is possible that the resilience of coral reefs, i.e. the capacity of a system to resist or recover from changes, would be primarily due to the presence of large-bodied herbivorous fishes. However, in many parts of the world the numbers of large parrotfish individuals are declining because of overfishing (Bellwood et al. 2003, Graham et al. 2005, Floeter et al. 2006, Mumby et al. 2006), a situation which may lead to phase shifts on coral reefs (Hughes 1994, Hughes et al. 2005, 2007). Given the varying impacts of different sized parrotfishes, it is clear that high fish number or biomass alone cannot be viewed as evidence of an intact ecosystem with fully operational ecosystem functions. The absolute size of individuals may be critical. Thus, when evaluating management options, managers should consider not only the numbers, identity and biomass of the species which might be protected, but also further characteristics, such as individual size and ontogenetic phase.

The functional role of fishes is not a species trait; it depends on the intraspecific variations, in which size is a critical factor. Although intra- and interspecific differences among reef herbivores have been known for a long time (e.g. Lewis \& Wainwright 1985, Carpenter 1986, Choat 1991, Floeter et al. 2005), their broader importance has only become evident recently, in the face of reef degradation and expanding threats to coral reefs (Bellwood et al. 2004, Mumby et al. 2006, Hughes et al. 2007). Thus, detailed studies on the functional role of reef species are essential, as they can provide important information about functional redundancy and coral reef resilience. In recognizing the importance of fish size, hopefully we can better understand the impacts of fishing activities and enable managers to formulate effective management strategies to protect coral reefs.

Acknowledgements. We thank J. H. Choat, L. Castell, R. Dunn and 3 anonymous reviewers for helpful comments; A. Gonzalez-Cabello, C. Cvitanovic, C. Ryen, D. Coker, J. P. Krajewski and J. Johansen for field assistance; Orpheus Island Research Station staff for logistical support; and the Australian Research Council, Great Barrier Reef Marine Park Authority and CAPES-Brazil for financial support.

\section{LITERATURE CITED}

Bellwood DR (1988) Ontogenetic changes in the diet of early post-settlement Scarus species. J Fish Biol 33:213-219

Bellwood DR (1995) Direct estimate of bioerosion by two parrotfish species, Chlorurus gibbus and C. sordidus, on the Great Barrier Reef, Australia. Mar Biol 121:419-429

Bellwood DR, Choat DR (1990) A functional analysis of grazing in parrotfishes (family Scaridae): the ecological implications. Environ Biol Fishes 28:189-214

Bellwood DR, Hoey AS, Choat JH (2003) Limited functional redundancy in high diversity systems: resilience and ecosystem function on coral reefs. Ecol Lett 6:281-285

Bellwood DR, Hughes TP, Folke C, Nystrom M (2004) Confronting the coral reef crisis. Nature 429:827-833

Bellwood DR, Hughes TP, Hoey AS (2006) Sleeping functional group drives coral reef recovery. Curr Biol 16:2434-2439

Birrell CL, McCook LJ, Willis BL (2005) Effects of algal turfs and sediment on coral settlement. Mar Pollut Bull 51: 408-414

Bonaldo RM, Krajewski JP, Sazima C, Sazima I (2006) Foraging activity and resource use by three parrotfish species at Fernando de Noronha Archipelago, tropical West Atlantic. Mar Biol 149:423-433

> Bruggemann JH, Begeman J, Bosma EM, Verburg P, Breeman AM (1994a) Foraging by the stoplight parrotfish Sparisoma viride. II. Intake and assimilation of food, protein and energy. Mar Ecol Prog Ser 106:57-71

Bruggemann JH, Kuyper MWM, Breeman AM (1994b) Comparative analysis of foraging and habitat use by the sympatric Caribbean parrotfish Scarus vetula and Sparisoma viride. Mar Ecol Prog Ser 112:51-66

Bruggemann JH, van Oppen MJH, Breeman AM (1994c) Foraging by the stoplight parrotfish Sparisoma viride. I. Food selection in different, socially determined habitats. Mar Ecol Prog Ser 106:41-55

Burkepile DE, Hay ME (2006) Herbivore versus nutrient control of marine producers: context-dependent effects. Ecology 87:3128-3139

> Carpenter RC (1986) Partitioning herbivory and its effects on coral reef algal communities. Ecol Monogr 56:345-364

Ceccarelli DM, Jones GP, McCook LJ (2005) Foragers versus farmers: contrasting effects of two behavioural groups of herbivores on coral reefs. Oecologia 145:445-453

Choat JH (1991) The biology of herbivorous fishes on coral reefs. In: Sale PF (ed) The ecology of fishes on coral reefs. Academic Press, San Diego, CA, p 120-155

Choat JH, Bellwood DR (1985) Interactions amongst herbivorous reef fishes on a coral reef: influence of spatial variation. Mar Biol 89:221-234

Choat JH, Clements KD, Robbins WD (2002) The trophic status of herbivorous fishes on coral reefs 1: dietary analysis. Mar Biol 140:613-623

Crossman DJ, Choat JH, Clements KD (2001) Detritus as food for grazing fishes on coral reefs. Limnol Oceanogr 46:1596-1605

> Crossman DJ, Choat JH, Clements KD (2005) Nutritional ecology of nominally herbivorous fishes on coral reefs. Mar Ecol Prog Ser 296:129-142

Diaz-Pullido G, McCook LJ (2004) Effects of live coral, epilithic algal communities and substrate type on algal recruitment. Coral Reefs 32:225-233

> Floeter SR, Behrens MD, Ferreira CEL, Paddack MJ, Horn $\mathrm{MH}$ (2005) Geographical gradients of marine herbivorous fishes: patterns and processes. Mar Biol 147:1435-1447

> Floeter SR, Halpern BS, Ferreira CEL (2006) Effects of fishing and protection on Brazilian reef fishes. Biol Conserv 128:391-402

Fox RJ, Bellwood DR (2007) Quantifying herbivory across a coral reef depth gradient. Mar Ecol Prog Ser 339:49-59

Graham NAJ, Dulvy NK, Jennings S, Polunin NVC (2005) Size-spectra as indicators of the effects of fishing on coral reef fish assemblages. Coral Reefs 24:118-124

Hay ME (1991) Fish-seaweed interactions on coral reefs: effects of herbivorous fishes and adaptations of their prey. In: Sale PF (ed) The ecology of fishes on coral reefs. Academic Press, San Diego, CA, p 96-119

Hixon MA, Brostoff WN (1996) Succession and herbivory: 
effects of differential fish grazing on Hawaiian coral-reef algae. Ecol Monogr 66:67-90

Hoey AS, Bellwood DR (2007) Cross shelf variation in the role of parrotfishes on the Great Barrier Reef. Coral Reefs. doi:10.1007/s00338-007-0287-x

Hughes TP (1994) Catastrophes, phase shifts, and large-scale degradation of a Caribbean coral reef. Science 265: $1547-1551$

Hughes TP, Baird AH, Bellwood DR, Card M and others (2003) Climate change, human impacts, and the resilience of coral reefs. Science 301:929-933

Hughes TP, Bellwood DR, Folke C, Steneck RS, Wilson J (2005) New paradigms for supporting the resilience of marine ecosystems. Trends Ecol Evol 20:380-386

Hughes TP, Rodrigues MJ, Bellwood DR, Ceccarelli D and others (2007) Phase shifts, herbivory, and the resilience of coral reefs to climate change. Curr Biol 17:360-365

Kulbicki M, Guillemot N, Amand M (2005) A general approach to length-weight relationships for New Caledonian lagoon fishes. Cybium 29:235-252

Lewis SM, Wainwright PC (1985) Herbivore abundance and grazing intensity on a Caribbean coral reef. J Exp Mar Biol Ecol 87:215-228

Littler MM, Littler DS (2006) Assessment of coral reefs using herbivory/nutrient assays and indicator groups of benthic primary producers: a critical synthesis, proposed protocols, and critique of management strategies. Aquat Conserv: Mar Freshwat Ecosyst 16:1-21

Mantyka CS, Bellwood DR (2007a) Direct evaluation of macroalgal removal by herbivorous reef fishes. Coral Reefs 26:435-442

Mantyka CS, Bellwood DR (2007b) Macroalgal grazing selectivity among herbivorous coral reef fishes. Mar Ecol Prog Ser 352:177-185

McClanahan TR, Glaesel H, Rubens J, Kiambo R (1997) The effects of traditional fisheries management on fisheries yields and the coral-reef ecosystems of southern Kenya. Environ Conserv 24:105-120

McCook LJ (1999) Macroalgae and phase shifts on coral reefs

Editorial responsibility: Charles Birkeland,

Honolulu, Hawaii, USA of the Great Barrier Reef and other regions: a perspective on scientific issues and management consequences. Coral Reefs 18:357-367

McManus JW, Polsenberg JF (2004) Coral-algal phase shifts on coral reefs: ecological and environmental aspects. Prog Oceanogr 60:263-279

> Mumby PJ, Dahlgren CP, Harborne AR, Kappel CV and others (2006) Fishing, trophic cascades and the process of grazing on coral reefs. Science 311:98-101

Nyström M, Folke C, Moberg F (2000) Coral reef disturbance and resilience in a human-dominated environment. Trends Ecol Evol 15:413-417

Purcell SW, Bellwood DR (2001) Spatial patterns of epilithic algal detrital resources on a windward coral reef. Coral Reefs 20:117-125

Steneck RS, Dethier MN (1994) A functional group approach to the structure of algal-dominated communities. Oikos 69:476-498

Strauss RE (1979) Reliability estimates for Ivlev's electivity index, the forage ratio, and a proposed linear index of food selection. Trans Am Fish Soc 108:344-352

Van Rooij JM, de Jong E, Vaandrager F, Videler JJ (1996a) Resource and habitat shared by the spotlight parrotfish, Sparisoma viride, a Caribbean reef herbivore. Environ Biol Fishes 47:81-91

Van Rooij JM, Kroon FJ, Videler JJ (1996b) The social and mating system of the herbivorous reef fish Sparisoma viride: one-male versus multi-male groups. Environ Biol Fishes 47:353-378

Wilson SK, Bellwood DR, Choat JH, Furnas MJ (2003) Detritus in the epilithic algal matrix and its use by coral reef fishes. Oceanogr Mar Biol Annu Rev 41:279-309

Wilson SK, Graham NAJ, Pratchett MS, Jones GP, Polunin NVC (2006) Multiple disturbances and the global degradation of coral reefs: Are fishes at risk or resilient? Glob Change Biol 12:2220-2234

Zemke-White WL, Choat JH, Clements KD (2002) A reevaluation of the diel feeding hypothesis for marine herbivorous fishes. Mar Biol 141:571-579

Submitted: September 22, 2007; Accepted: January 21, 2008 Proofs received from author(s): May 15, 2008 